\title{
Pov-Ray による雪の表現
}

山口 博史 Hiroshi YAMAGUCHI

辻合秀一 Hidekazu TSUZIAI

概要 : 本研究では, 雪の結晶および雪景観を Pov-Ray を用いて 3 次元のモデルを構築する.Pov-Ray は,

ソリッドモデルの表現や透明な物を表示寸ることが でき, 光源の位置や光の強さを調節することで, よ り現実に近い水や水を簡単に表現することができる. 本研究では, 水の結晶である雪を 1 つの小さ結晶 からこれを雪の塊にして大きくすると雪の見え方が どう変化するかをとらえる.

キーワード : $\mathrm{C} \mathrm{G} /$ 景観表現 $/ 3$ 次元

\section{1. はじめに}

古来より，雪というものは様々な表現方法がなさ れてきた. 江戸時代に代表される「水量画」などは 当時使用されていた白に近い紙を用い, 墨にて山々 や町並みなどの風景を表現し、これらの中に背景之 して雪の輪郭を書き加えることで，我々の想像力を 利用し，雪というものを忠実に表現している.また， 現代の C Gによる 3 次元での雪の表現としては, 雪 を模した形状のものつくりこれを白く塗ることによ り雪を表現する例 ${ }^{[1]}$ がある。しかし，これらの表現 方法で表される雪は，そのものを書いているのでは なく，その場を白く塗る，または白という色をその まま残し光の角度で見える影を枠として残すことに よって，見る側の想像で雪と判断させているのであ り，実際にはこれらを雪と判断することは我々しだ いである，そこで私は，普段は単体では表現されに くい雪そのものを表現することを試みる，つまり， 実際の雪はどのようなもので, どのようにして精製 されるのかを調べこれらを元にPov-Ray ${ }^{[2]-[3]}$ という C G を作るソフトを利用し，どこまで C G の雪が本 物に見えるのかどうかを目的として研究を行なう。 そして, 出来上がった雪の画を, 写真や $\mathrm{CG}$ で作っ た 3 次元の画像などに合成することで, どこまで本 物の雪の画に近づけるか検証を行なう.

\section{2. 本研究に使用するソフトと調査·研究方法}

\subsection{Pov-Ray を使用しての雪の結晶の作成}

今回は, 「Pov-Ray」という3 次元の C G (コンピュ ータグラフィック)を作成するフリーソフトを使用 する.このソフトは，「テキスト一括方式」[1] を用い て作業を行う。つまり, 作成する C G 関するデー タを文書化して, まとめてコンピュータに指示を与 えることで, C G を作成する. 作業方法は空間の座 標軸(本研究では横軸を $\mathrm{x}$ 軸, 縦軸を $\mathrm{y}$ 軸, 高さを $\mathrm{z}$ 軸とした）を指定し，その他様々な要素を数值や文 章で入力することで, 様々な物体を表現することで きる，例えば, 「空間の座標軸 $\mathrm{x}, \mathrm{y}, \mathrm{z}$ に, 半径 $5 \mathrm{~cm}$ の白色の球体をつくる」などの指示を与えると, 指 示通りの作業をコンピュータが行うのである (図 1).
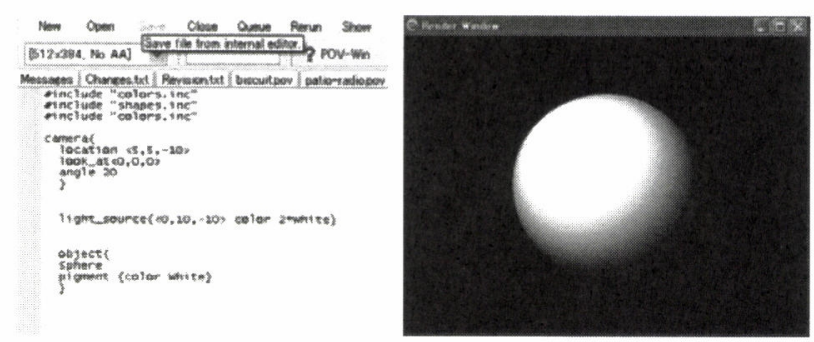

\section{図1 コンピュータへの指示文と出カ画像}

ここで本題だが，雪というのは上空の雲の中にあ る水分が固まり, 小さな水の粒が出来る。これらが 次第に固まり, 粒が大きくなり, 重くなることで降 ってくる.こうして, 白い雪の結晶が降り積もり, 我々が良く見る雪景観となる。しかし, 雪というも のは実際には白いわけではない. 細かな水の粒が幾 重にも重なり，そこに光があたることによって塊の 中で全ての光が遮断されることなく反射するので, 白く見えているのである。例えば、赤色の波形しか 持たない光を当てると, 赤色が白色と混ざり薄まる のではなく, 真っ赤な雪に見える。しかし, 現代の 雪の表現方法は雪を模した物体を白く塗るやり方を 
している(図 2)。そこで私は, Pov-Rayを利用し, 雪の結晶を C G で作成することで, 雪の結晶 ${ }^{[4]}$ を再 現する.これらを幾重にも重祇るというやり方をと る。これは，実際に雪が降り固まる工程を，CGを 利用して再現することで, 現実の雪をよりリアルに 再現できないか，という仮説を立てて検証する.

まずは雪の結晶には様々な形があるが，一番我々 になじみがあるであろう六角形をべースとした結晶 （図 3 ）を作る ${ }^{[5]}$. このオブジェクトの光透過率を 水と同じにし，ある空間内に何重にも重ねて光りを 当てて, どのように再現できるかを試みる. 現在は, ガラスと同じ透過率で, 雪（結晶群）を作成してい るが，まだ白さを表現するに至っていない。

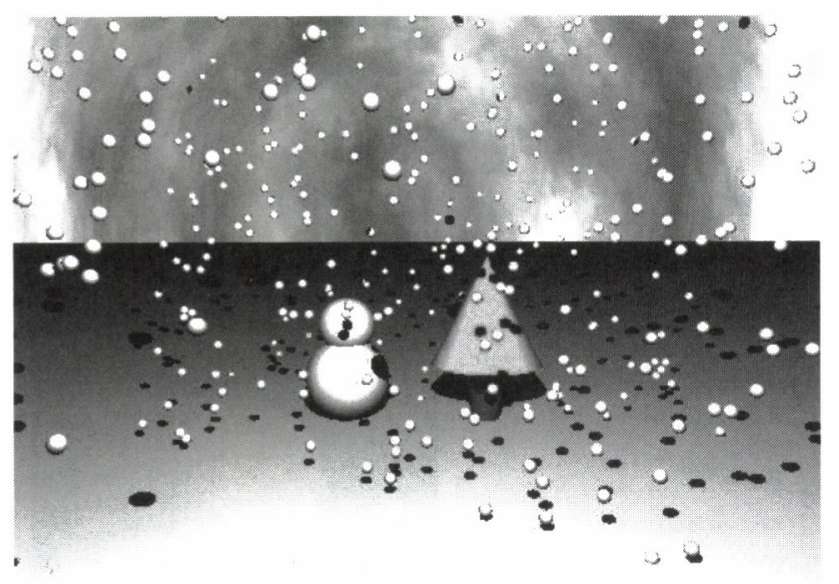

\section{図2 雪の表現方法}

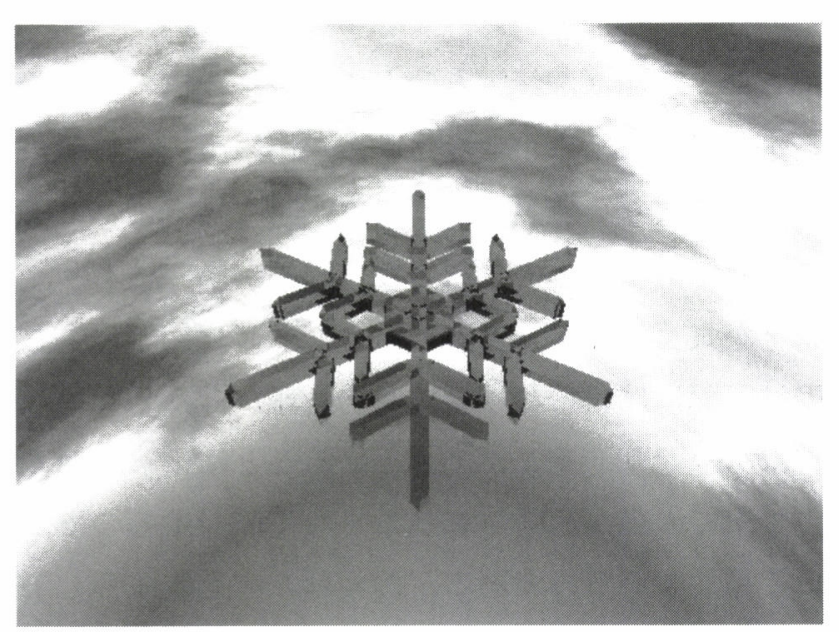

図3 Pov-Rayを利用し雪結晶の作成

\section{3. まとめ}

Pov-Ray を用いた今回の研究は雪を 3 次元に作成 し，それがいかに現実の雪に近く見えるかについて の研究である、現段階では, 同ソフトを使用した風 景の再現により研究を行っているが，この雪の C G を実際の写真などの静止画に用いることは可能か, またこれらのデータを動画に使用することが可能で あるか，これからの研究課題である。

\section{参考文献}

[1]吉田 祐佳, 辻合 秀一, “雪の色表現モデル” , 日本図学会中部支部講演・研究発表会, (2006)

[2]石本 浩次, “POV-RAY for Windows 入門”, ソシ 么, (1998)

[3] 小室 日出樹, “POV-Ray ではじめるレイトレーシ ング”,アスキー, (1998)

[4] 中谷 宇吉郎, “雪”, 岩波書店, (1994)

[5]光田 早希, 辻合 秀一, “雪の結晶生成過程モデ ル構築”, 日本図学会中部支部講演・研究発表会, (2006)

\section{著者紹介}

やまぐち ひろし：富山大学高岡短期大学部専攻 科地域ビジネス専攻

933-8588, 富山県高岡市二上町 180

つじあいひでかず：昭和 58 年甲南大理学部応用 数学科卒. 昭和 61 年大阪府大学大学院総合科学研究 科修士課程修了. 昭和 62 年近畿大学理工学部助手. 平成 5 年同大生物理工学部講師. 平成 17 年富山大学 芸術文化学部助教授. 平成 19 年准教授. 博士 (工学). C G および画像処理などの研究に従事. 日本図学会, 芸術科学会, 日本デザイン学会, 情報処理学会, シス テム制御情報学会, IEEE, IGGG 等の各会員.

933-8588, 富山県高岡市二上町 180 